\title{
Quantification of oxalate ions and protons released by ectomycorrhizal fungi in rhizosphere soil
}

\author{
Valter CASARIN ${ }^{\mathrm{a}}$, Claude PLASSARD ${ }^{\mathrm{b} *}$, Gérard SOUCHE ${ }^{\mathrm{b}}$, Jean-Claude ARVIEU $^{\mathrm{b}}$ \\ ${ }^{a}$ Soil Science Department, São Paulo University, ESALQ, C.P. 9, 13418-900, Piracicaba (SP), Brazil \\ ${ }^{\mathrm{b}}$ Sol et Environnement, UMR 388, AgroM-INRA, place Viala, 34060 Montpellier Cedex 01, France
}

(Received 6 August 2002; accepted 23 December 2002)

\begin{abstract}
This paper deals with the study of proton and oxalate release by two ectomycorrhizal fungi, Hebeloma cylindrosporum and Rhizopogon roseolus, grown alone or in association with Pinus pinaster and supplied with nitrate. An original culture device made it possible to observe the growth of the ectomycorrhizal roots and to measure $\mathrm{pH}$ and oxalate content at different levels: roots, ectomycorrhizae, external hyphae and rhizosphere soil. The results showed differences between the two species grown in vitro. These differences were strictly maintained in association with the plant. $R$. roseolus strongly acidified the rhizosphere and released oxalate. This oxalate excretion was enhanced by $\mathrm{CaCO}_{3}$ in the soil. A strong correlation appeared between $\mathrm{pH}$ and oxalate contents in rhizosphere soil, indicating that oxalate ions and protons were released simultaneously. H. cylindrosporum did not release these ions and tended to alkalinise rhizosphere soil. Such chemicals, released by $R$. roseolus, could contribute to the mobilisation of $\mathrm{P}$ from soil.
\end{abstract}

oxalate / protons / R. roseolus / H. cylindrosporum / Pinus pinaster

Résumé - Quantification des ions oxalate et des protons libérés par les champignons ectomycorhiziens dans le sol rhizosphérique. Cet article porte sur l'étude des excrétions de protons et d'oxalate en nutrition nitrique par deux champignons ectomycorhiziens, Hebeloma cylindrosporum et Rhizopogon roseolus, en culture isolée ou en association avec Pinus pinaster. Un dispositif original de culture sur couche mince de sol a permis d'observer la croissance des racines mycorhizées et de mesurer le $\mathrm{pH}$ et l'oxalate à différents niveaux : racines, mycorhizes, hyphes externes et sol rhizosphérique. Les résultats montrent des différences de comportement entre espèces fongiques en culture pure, différences strictement conservées dans l'association avec la plante. $R$. roseolus acidifie fortement la rhizosphère et l'excrétion de protons s'accompagne d'une excrétion d'oxalate, favorisée par la présence de $\mathrm{CaCO}_{3}$ dans le sol. Une corrélation étroite existe entre le pH et la teneur en oxalate du sol rhizosphérique, indiquant que les ions oxalate et protons sont excrétés simultanément. $H$. cylindrosporum ne présente pas ces propriétés et a tendance à alcaliniser le sol rhizosphérique. Ces actions chimiques exercées par $R$. roseolus pourraient contribuer à la mobilisation de $\mathrm{P}$ du sol.

oxalate / protons / R. roseolus / H. cylindrosporum / Pinus pinaster

\section{INTRODUCTION}

Mediterranean forests are generally established in low fertility soils, without any applied fertiliser. In addition, these soils are often calcareous, and have high contents of iron oxides with high capacities for phosphorus fixation. The growth of the trees relies on the root capacity to use natural soil resources such as mineral P. Among the factors governing $\mathrm{P}$ dissolution, rhizosphere $\mathrm{pH}$ modifications and organic anion release are thought to be the most important [9]. Medium acid- ification can dramatically increase the dissolution of apatites or natural phosphates in the plant rhizosphere $[6,10,11,15$, $16,20,24,30]$. In plants, nitrogen supply is a key factor for rhizosphere $\mathrm{pH}$, as a supply of $\mathrm{NH}_{4}{ }^{+}$will result in acidification, whereas $\mathrm{NO}_{3}{ }^{-}$will result in alkalisation of the medium [21]. However, at external $\mathrm{pH}$ higher than 6.0, acidification zones can be observed with nitrate nutrition, due to the release of respiratory $\mathrm{CO}_{2}$ in the rhizosphere. $\mathrm{CO}_{2}$ will dissolve in water to produce the weak acid $\mathrm{H}_{2} \mathrm{CO}_{3}$, that dissociates into $\mathrm{H}^{+}$and $\mathrm{HCO}_{3}{ }^{-}(\mathrm{pK}=6.35)[9,12]$. 
Regarding organic anion production, it has been shown that many soil fungi are able to produce and excrete oxalate. However, as pointed out by Dutton and Evans [2] and Gadd [5], numerous studies were carried out on saprophyte or pathogenic fungi. In contrast, studies dealing with mycorrhizal fungi are fewer and limited to some species such as the Basidiomycete Paxillus involutus. In pure culture conditions, it was demonstrated that the different forms of $\mathrm{N}$ affect oxalate synthesis by this fungal species. Compared with ammonium, nitrate supply markedly favours oxalate production $[5,7,18]$. Besides the effect of the N-source, bicarbonate ions also enhance oxalate production by $P$. involutus [17]. These studies were extended to several ectomycorrhizal fungal species able to use $\mathrm{NO}_{3}{ }^{-}$as the sole source of $\mathrm{N}$ in pure culture, demonstrating that some fungal species (Rhizopogon roseolus, Suillus collinitus and Paxillus involutus) were able to release high amounts of oxalate, whereas others were not (Hebeloma cylindrosporum) [1, 19]. It was also shown that $R$. roseolus exhibited a significant efflux of protons together with oxalate, whereas $H$. cylindrosporum always alkalinised the solution. The addition of $\mathrm{CaCO}_{3}$ enhanced both oxalate and proton effluxes by oxalate-producing fungi, increasing the chemical action exerted by the fungi on the mineral. These specific fungal capacities, if retained by the hyphae growing in association with the plant, could therefore help us to identify and to assess the role of chemicals released by these fungi in $\mathrm{P}$ mobilisation under Mediterranean soil conditions.

In this study we chose two fungal species exhibiting contrasting abilities in pure culture regarding proton and oxalate release, $H$. cylindrosporum and $R$. roseolus, in order to quantify the ability of these fungi to chemically alter a fersialitic soil, supplemented or not with mineral $\mathrm{P}$ or $\mathrm{CaCO}_{3}$. Fungi were grown either in pure culture or in association with Pinus pinaster. Plants were grown in special rhizoboxes with a thin layer of soil, enabling us to quantify $\mathrm{H}^{+}$and oxalate release at the level of the roots, whether non-mycorrhizal or mycorrhizal, the fungus or the rhizosphere soil.

\section{MATERIALS AND METHODS}

\subsection{Plant and fungal material}

Both fungal species used in this study, Hebeloma cylindrosporum Romagn. (isolate 9) and Rhizopogon roseolus (Corda) Th. Fr, were isolated from sporocarps harvested in acidic and calcareous sandy soil, respectively. Fungal stock cultures were grown at $24{ }^{\circ} \mathrm{C}$ in the dark, in Petri dishes containing an agar $\left(14 \mathrm{~g} \cdot \mathrm{l}^{-1}\right)$ medium in the following nutrient solution (N6): $6 \mathrm{mM} \mathrm{KNO}_{3}, 4 \mathrm{mM} \mathrm{KCl}, 1 \mathrm{mM} \mathrm{NaH}{ }_{2} \mathrm{PO}_{4}$, $1 \mathrm{mM} \mathrm{CaCl}_{2}, 1 \mathrm{mM} \mathrm{NaCl}, 1 \mathrm{mM} \mathrm{MgSO}_{4} 7 \mathrm{H}_{2} \mathrm{O}, 100 \mu \mathrm{g} \cdot \mathrm{l}^{-1}$ thiamine- $\mathrm{HCl}, 10 \mathrm{mg} \cdot \mathrm{l}^{-1}$ ferric citrate, $0.2 \mathrm{ml} \cdot \mathrm{l}^{-1}$ of Morizet and Mingeau micronutrients solution [22] and $110 \mathrm{mM}$ glucose.

Seedlings of maritime pine (Pinus pinaster Soland. in Ait., from Medoc, Landes-Sore-VG source, France) were obtained from seeds that were surface-sterilised with $30 \%$ (w/w) $\mathrm{H}_{2} \mathrm{O}_{2}$ solution for $30 \mathrm{~min}$, then rinsed with sterile distilled water. Germination was carried out on water agar gel $\left(14 \mathrm{~g} \cdot \mathrm{l}^{-1}\right)$ containing $2 \mathrm{~g} \cdot \mathrm{1}^{-1}$ glucose. Mycorrhizal synthesis was carried
Table I. Physical and chemical characteristics of Cazevieille soil sieved at $210 \mu \mathrm{m}$.

\begin{tabular}{|c|c|}
\hline \multicolumn{2}{|l|}{ Physical characteristics: soil granulometry $\left(\mathrm{g} \cdot \mathrm{kg}^{-1}\right)$} \\
\hline Clay $(<2 \mu \mathrm{m})$ & 485 \\
\hline Fine silt ( 2 to $20 \mu \mathrm{m})$ & 218 \\
\hline Coarse silt ( 20 to $50 \mu \mathrm{m})$ & 178 \\
\hline Fine sand (50 to $200 \mu \mathrm{m}$ ) & 116 \\
\hline Coarse sand (200 to $2000 \mu \mathrm{m})$ & 3 \\
\hline \multicolumn{2}{|l|}{ Chemical characteristics } \\
\hline $\mathrm{pH}$ in water & 6.9 \\
\hline Total $\mathrm{CaCO}_{3}\left(\mathrm{~g} \cdot \mathrm{kg}^{-1}\right)$ & $<1$ \\
\hline Cation exchange capacity - Metson's method $\left(\mathrm{cmol}_{\mathrm{c}} \cdot \mathrm{kg}^{-1}\right)$ & 21.6 \\
\hline Calcium $\mathrm{CH}_{3} \mathrm{COONH}_{4}$ exchangeable $\left(\mathrm{cmol}_{\mathrm{c}} \cdot \mathrm{kg}^{-1}\right)$ & 18.5 \\
\hline Magnesium $\mathrm{CH}_{3} \mathrm{COONH}_{4}$ exchangeable $\left(\mathrm{cmol}_{\mathrm{c}} \cdot \mathrm{kg}^{-1}\right)$ & 1.2 \\
\hline Potassium $\mathrm{CH}_{3} \mathrm{COONH}_{4}$ exchangeable $\left(\mathrm{cmol}_{\mathrm{c}} \cdot \mathrm{kg}^{-1}\right)$ & 0.45 \\
\hline Organic carbon - Anne's method $\left(\mathrm{g} \cdot \mathrm{kg}^{-1}\right)$ & 24.1 \\
\hline Organic matter $\left(\mathrm{g} \cdot \mathrm{kg}^{-1}\right)$ & 41.5 \\
\hline Total organic $\mathrm{N}-$ Kjeldahl's method $\left(\mathrm{g} \cdot \mathrm{kg}^{-1}\right)$ & 2.49 \\
\hline $\mathrm{P}-$ Olsen's method $\left(\mathrm{mg} \cdot \mathrm{kg}^{-1}\right)$ & 3.1 \\
\hline Total P HF $\left(\mathrm{g} \cdot \mathrm{kg}^{-1}\right)$ & 0.908 \\
\hline Total Fe $\left(\mathrm{g} \cdot \mathrm{kg}^{-1}\right)$ & 0.463 \\
\hline
\end{tabular}

out in test tubes with germinated seedlings, as previously described in Plassard et al. [26]. Plants, whether inoculated or not, were grown in test tubes for 2 months, with nutrient solution (10 $\mathrm{ml}$ per tube) of the same composition as in Plassard et al. [26] and renewed every week under sterile conditions. All the plants were grown in a growth chamber under a 16/8 h light/dark cycle at $25 / 20{ }^{\circ} \mathrm{C}, 80 / 100 \%$ relative humidity, $\mathrm{CO}_{2}$ concentration of ca. $350 \mathrm{~mm}^{3} \cdot 1^{-1}$ and a PAR of approximately $400 \mu \mathrm{mol} \cdot \mathrm{m}^{-2} \cdot \mathrm{s}^{-1}(400-700 \mathrm{~nm})$.

\subsection{Soil collection and preparation}

The soil used was collected from the A horizon of a fersialitic soil in southern France (Cazevieille, Hérault). Before use, the soil was air-dried, crushed gently and sieved at $210 \mu \mathrm{m}$. Physical and chemical analysis (Tab. I) showed that its $\mathrm{pH}$ was close to neutrality, with a cation exchange capacity mainly saturated by calcium. In addition, it had high levels of iron and total P but a very low level of soluble P (estimated as Olsen P).

The soil was used either without any treatment (NT) or after addition of calcium carbonate $\left(200 \mathrm{~g} \cdot \mathrm{kg}^{-1}\right.$ dry soil $)\left(\mathrm{CaCO}_{3}\right)$, or $\mathrm{P}\left(350 \mathrm{mg} \cdot \mathrm{kg}^{-1}\right.$ dry soil) supplied as hydroxylapatite (HA) or $\mathrm{KH}_{2} \mathrm{PO}_{4}$ (MKP). $\mathrm{CaCO}_{3}$ mineral was a reagent grade commercial product (Merck 2066) and hydroxylapatite was synthesised according to Hayek and Stadlmann [8]. HA soil was obtained by suspending $100 \mathrm{~g}$ of dried soil in one litre of deionised water containing $189 \mathrm{mg}$ of HA. MKP soil was obtained by mixing $100 \mathrm{~g}$ of dry soil in one litre of deionised water containing $\mathrm{KH}_{2} \mathrm{PO}_{4} 1.186 \mathrm{mM}$, pH 7.0. Soil suspensions were stirred for $72 \mathrm{~h}$ and centrifuged. The phosphorus concentration 


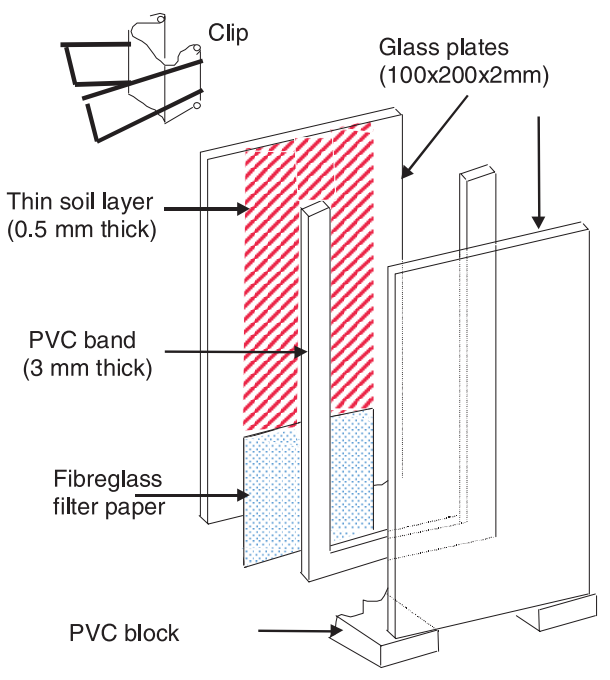

Figure 1. Scheme of the rhizobox designed for culture of Pinus pinaster plants on a thin layer of soil.

of the supernatant was very low (data not shown). This indicates that added phosphorus was firmly adsorbed on the iron oxihydroxides of the soil. After rinsing, water amounting to $25 \%$ of the wet soil mass was added to the centrifugation pellets put in plastic bags. Non-treated soil and $\mathrm{CaCO}_{3}$ soil were mixed with deionised water $(1 / 1, w / w)$ in plastic bags. The different soils were sterilised twice a week by autoclaving them for $40 \mathrm{~min}$ at $114{ }^{\circ} \mathrm{C}$. The efficiency of this sterilisation treatment was controlled by measuring soil respiration, which became not detectable only after the second autoclaving. Soil samples were then kept sterile, at $4{ }^{\circ} \mathrm{C}$, before use.

\subsection{Culture devices}

Plants, whether mycorrhizal or not, were grown in mini rhizoboxes similar to those described by Kirk et al. [16], that are presented in Figure 1. They were made from 2 glass plates $(100 \times 200 \times 2 \mathrm{~mm})$ separated by a PVC band. All of the setting up of each mini rhizobox with the plant was carried out in sterile conditions. Every piece of the boxes was cleaned with a solution containing ethanol $(70 \%, \mathrm{v} / \mathrm{v})$ and sodium hypochloride $(5 \%)$ in a laminar flow cabinet. A soil layer (500 $\mu \mathrm{m}$ thick) was spread out on one side of a glass plate by using previously disinfected material for chromatography thin layer preparation. After air drying in sterile conditions, the thin soil layer was cut around the edges of the glass to enable us to put the PVC band ( $3 \mathrm{~mm}$ thick, $1 \mathrm{~cm}$ wide) on the glass. A piece of fibreglass filter paper (Whatmann, Ref. 1822.14), previously sterilised $\left(120^{\circ} \mathrm{C}\right.$, $20 \mathrm{~min}$, twice at $48 \mathrm{~h}$ intervals), was added to the lower part of the soil layer. The plant, with roots previously aseptically grown in tubes, was put on the surface of the soil layer before adding the second glass plate on the top of the roots. The root boxes were then closed with 4 drawing clips fixed on the sides and sticky tape fixed on the top of the box to minimise water evaporation. Finally the root boxes were taken out of the laminar flow cabinet and placed in a PVC box previously cleaned with the ethanol-sodium hypochloride solution. The PVC boxes with the plants were placed in the growth chamber as previously described. Plants were continuously supplied with a simplified nutrient solution containing $1 \mathrm{mM} \mathrm{KNO}{ }_{3}, 0.2 \mathrm{ml} \cdot \mathrm{l}^{-1}$ of Morizet and Mingeau micronutrients solution [22], $\mathrm{pH}$ 6.0. The solution, previously autoclaved $\left(120{ }^{\circ} \mathrm{C}, 20 \mathrm{~min}\right)$, was added to the $\mathrm{PVC}$ box at the rate of $50 \mathrm{ml} \cdot$ plant $^{-1}$. The solution was renewed every week, in non-sterile conditions, in the growth chamber. The duration of the culture was 3 months.

Both fungi were grown in vitro in sterile conditions in Petri dishes with 2 compartments. One of the compartments was filled with $18 \mathrm{ml}$ of agarose $\left(14 \mathrm{~g} \cdot \mathrm{1}^{-1}\right.$, from Fluka, Ref. 05068) medium containing $0.25 \mathrm{mM} \mathrm{KNO}, 0.1 \mathrm{mM} \mathrm{NaH} \mathrm{PO}_{4}$, $100 \mu \mathrm{g} \cdot \mathrm{l}^{-1}$ thiamine- $\mathrm{HCl}$ and $55 \mathrm{mM}$ glucose. The other compartment was filled with $3 \mathrm{~g}$ of soil paste made by mixing dry soil with a nutrient solution $(1 / 1, \mathrm{w} / \mathrm{v})$ containing $1 \mathrm{mM} \mathrm{KNO}_{3}$ and $0.2 \mathrm{ml} \cdot 1^{-1}$ of Morizet and Mingeau micronutrients solution [22]. A small piece of filter paper was put between compartments to facilitate the crossing of the mycelium, previously inoculated in the agar compartment by placing a fungal plug ( $8 \mathrm{~mm}$ in diameter) in its centre. The dishes were then placed at $23{ }^{\circ} \mathrm{C}$, in the dark, for 3 months.

\subsection{Sampling}

At the end of the culture in the rhizoboxes, before opening the boxes, the development of non-mycorrhizal roots, ectomycorrhizal short roots and hyphae on the soil surface was recorded by tracing them on a transparent sheet placed over the glass plate. This drawing was used to precisely spot the sampling zones of each plant. The root boxes were then opened and $\mathrm{pH}$ measurements were carried out immediately on the surface of bulk soil, non-mycorrhizal roots, ectomycorrhizal roots and external hyphae. The glass plate with the soil layer and the plant was then freeze-dried as a whole. The Petri dishes with fungal species in pure culture were also opened and freeze-dried before soil sampling and analysis.

After freeze-drying, the plant was gently drawn out from the soil in order to get all short roots and hyphae. In mycorrhizal plants, the external hyphae remaining on the soil were sampled as completely as possible using forceps. Samples of hyphae were taken for observations by scanning electron microscope (Jeol, JSM T 300 LGS) after gold treatment (Ref. Jeol, JFC1100). The plants were then separated into shoots, mycorrhizal roots with hyphae and non-mycorrhizal roots. The soil of the root boxes was sampled using the drawing and separated into 2 parts: (i) the bulk soil, free of mycelium or roots; and (ii) the rhizosphere soil, previously occupied by the roots, (non-mycorrhizal plants) or by the ectomycorrhizae and the hyphae (mycorrhizal plants). For the fungal cultures carried out in Petri dishes, the soil was also sampled into 2 parts corresponding to the bulk soil and the soil occupied by the hyphae. Each sample was then weighed and milled before analysis.

\subsection{Chemical analysis}

Measurements of $\mathrm{pH}$ were carried out in two different ways. Firstly, pH was measured on the surface of living non-mycorrhizal roots, ectomycorrhizal roots, hyphae and bulk soil, using pieces of $\mathrm{pH}$ paper (Macherey-Nagel) giving $\mathrm{pH}$ values ranging 
Table II. Ergosterol contents, $\mathrm{pH}$ and oxalate contents of soil occupied by the hyphae of two ectomycorrhizal basidiomycetes, Rhizopogon roseolus (R.r) and Hebeloma cylindrosporum (H.c) grown in vitro. The soil was used either without any treatment (NT) or after addition of calcium carbonate $\left(200 \mathrm{~g} \cdot \mathrm{kg}^{-1}\right.$ dry soil $)\left(\mathrm{CaCO}_{3}\right)$, or $\mathrm{P}\left(350 \mathrm{mg} \cdot \mathrm{kg}^{-1}\right.$ dry soil $)$ supplied as hydroxylapatite $(\mathrm{HA}) \mathrm{Or} \mathrm{KH}_{2} \mathrm{PO}_{4}(\mathrm{MKP})$. Data are means \pm standard deviation ( $\mathrm{n}=2$ to 5 according to the number of replicates with sufficient development).

\begin{tabular}{|c|c|c|c|c|c|}
\hline \multirow[b]{2}{*}{ Variable } & \multirow{2}{*}{$\begin{array}{l}\text { Fungal } \\
\text { species }\end{array}$} & \multicolumn{4}{|c|}{ Soil treatment } \\
\hline & & NT & $\mathrm{CaCO}_{3}$ & HA & MKP \\
\hline \multirow[t]{4}{*}{$\overline{\text { Ergosterol }\left(\mu \mathrm{g} \cdot \mathrm{g}^{-1} \mathrm{~d} \text { soil }\right)}$} & H.c & $6.2 \pm 1.9_{\mathrm{b} \$ \$}$ & $2.2 \pm 1.0$ & $13.6 \pm 3.6^{\mathrm{a} \$}$ & $16.5 \pm 3.1^{\mathrm{a}}{ }_{\mathrm{a}}$ \\
\hline & $\mathrm{n}^{*}$ & 3 & 2 & 5 & 5 \\
\hline & R.r & $\mathrm{nd}^{* *}$ & nd & $12.6 \pm 2.8^{\mathrm{a}}{ }_{\mathrm{a}}$ & $4.5 \pm 2.4_{\mathrm{b}}^{\mathrm{b}}$ \\
\hline & $\mathrm{n}$ & 1 & 2 & 4 & 5 \\
\hline \multirow[t]{3}{*}{$\mathrm{pH}\left(\mathrm{H}_{2} \mathrm{O}\right)$} & none $e^{\mathfrak{f}}$ & $7.10 \pm 0.08^{\mathrm{a} \$} b \$$ & $7.55 \pm 0.08_{\mathrm{a}}$ & $7.16 \pm 0.08^{\mathrm{a}}{ }_{\mathrm{b}}$ & $7.29 \pm 0.10^{\mathrm{a}} \mathrm{b}$ \\
\hline & H.c & $7.60 \pm 0.06^{\mathrm{a}}$ & $7.53 \pm 0.07$ & $7.32 \pm 0.08^{\mathrm{a}}{ }_{\mathrm{a}}$ & $7.29 \pm 0.10^{\mathrm{a}} \mathrm{a}$ \\
\hline & R.r & 6.92 & $7.29 \pm 0.06$ & $6.47 \pm 0.20^{\mathrm{b}}{ }_{\mathrm{a}}$ & $6.79 \pm 0.14^{\mathrm{b}}{ }_{\mathrm{a}}$ \\
\hline \multirow[t]{2}{*}{ Oxalate $\left(\mu \mathrm{mol} \mathrm{C} \mathrm{C}_{2} \mathrm{O}_{4}{ }^{2-} \cdot \mathrm{g}^{-1} \mathrm{~d}\right.$ soil $)$} & H.c & $\mathrm{nd}^{\mathfrak{f} \mathfrak{f}}$ & nd & nd & nd \\
\hline & R.r & 3.6 & $3.5 \pm 0.11$ & $16.0 \pm 14_{\mathrm{a}}$ & $7.1 \pm 2.6_{a}$ \\
\hline
\end{tabular}

$*: \mathrm{n}=$ number of replicates with sufficient fungal development $/ 6$ replicates initially in culture; $* *: \mathrm{nd}=$ not detectable $\left(<1.2 \mu \mathrm{g}\right.$ ergosterol $\cdot \mathrm{g}^{-1} \mathrm{dry}$ soil); $£: \mathrm{n}=6 ;{ }^{\$}$ : for a given variable, means $(\mathrm{n}>2)$ in each column followed by a different superscript letter are significantly different at $P=0.05 ; \$ \$$ : means $(\mathrm{n}>2)$ in each line followed by a different subscript letter are significantly different at $P=0.05 ;$ f $^{\prime}$ : nd $=$ not detectable $\left(<0.3 \mu \mathrm{mol}\right.$ oxalate $\cdot \mathrm{g}^{-1} \mathrm{dry}$ soil $)$.

from $\mathrm{pH} 4.0$ to 9.0 ( \pm 0.2 unit). The validity of these measurements was assessed using $\mathrm{H}^{+}$selective microelectrodes [27] or a flat glass combined electrode (Metrohm, Ref. 6.0217.000). Secondly, $\mathrm{pH}$ of the rhizosphere soil was measured according to the usual methods by using a glass combined electrode (Metrohm, Ref. 6.0204.000) in soil water suspensions (1/2.5, w/v), previously shaken overnight end-over-end.

Ergosterol contents of freeze-dried roots (non-mycorrhizal roots or ectomycorrhizae and hyphae) or rhizosphere soil were measured according to the method given in Plassard et al. [28]. Briefly, ergosterol from fungal cell membranes was extracted by incubating $0.5 \mathrm{~g}$ of soil or $0.2 \mathrm{~g}$ of roots in $3 \mathrm{ml}$ of methanol containing polyclar $(0.5 \%, \mathrm{w} / \mathrm{v}$, from Serva, Ref. 33162). The concentration of ergosterol in filtered $(0.45 \mu \mathrm{m})$ methanol extracts was determined at $270 \mathrm{~nm}$ by high-performance liquid chromatography using a C18 column and eluted with methanol flowing at $1 \mathrm{ml} \cdot \mathrm{min}^{-1}$.

Oxalate was extracted from the samples and assayed according to the method developed by Piombo et al. [25], modified for small-sized samples. Freeze-dried soil $(0.5 \mathrm{~g})$ or roots $(0.2 \mathrm{~g})$ were mixed with $5 \mathrm{ml}$ of $\mathrm{HCl}$, concentrated enough to dissolve $\mathrm{CaCO}_{3}$ in the sample and to get a final $\mathrm{HCl}$ normality of $0.5 \mathrm{~N}$ in the extract. Hydroxylamine chlorhydrate $\left(3 \mathrm{mg} \cdot \mathrm{ml}^{-1}\right.$ $\mathrm{HCl}$ ) was added to the mixture in order to avoid the production of highly stable, soluble complexes of oxalate with Fe III. The mixture was boiled for one hour and filtered. One $\mathrm{ml}$ of the filtrate was sampled and diluted 10 times before addition of $4 \mathrm{~g}$ of cation exchange resin (acidic form) in order to eliminate the cations (especially $\mathrm{Ca}^{++}$) from the solution. Oxalate and other anions were assayed in this treated solution by High Performance Ionic Chromatography (DIONEX 4000i) with a column of anionic resin (AS11 type). Anions were eluted with a gradient of $\mathrm{NaOH}$ made up from solutions of $\mathrm{NaOH}$ at $0.75 \mathrm{mM}$ (elutant 1) and $100 \mathrm{mM}$ (elutant 2), respectively, with the following steps: $0-3 \mathrm{~min}, 100 \%$ of elutant $1 ; 18 \mathrm{~min}, 70 \%$ of elut- ant 1 and $30 \%$ of elutant 2. Calibrations for retention times and peak areas were carried out with standard solutions containing oxalic acid or other organic anions, such as acids or salts of sodium or potassium. Peaks could be seen and quantified when the concentration of oxalate in the solution injected into the column was at least $10 \mu \mathrm{M}$.

\subsection{Statistics}

All results given are means and standard deviations. Unless specified, the number of replicates used to calculate the mean is five. When indicated, data were analysed by the one-way ANOVA procedure and significant differences between treatments determined by Scheffe's F-test using Statview ${ }^{\circledR}$ software (Abacus Concepts, USA) at $P=0.05$.

\section{RESULTS}

\subsection{Fungi grown in pure culture}

After three months of culture, only some replicates showed sufficient growth in the soil compartment with non-treated soil or supplemented with $\mathrm{CaCO}_{3}$ (Tab. II). The addition of phosphorus to the soil greatly improved the growth of the fungus, suggesting that soil available $\mathrm{P}$ was limiting the fungal growth. Observations carried out using a stereomicroscope showed that hyphae of $H$. cylindrosporum fully colonised the soil in depth whereas those of $R$. roseolus remained at the soil surface. However, in all treatments, the quantity of hyphae present in the soil was too low to permit measurement of their ergosterol and oxalate concentrations. Therefore, ergosterol and oxalate contents were measured only in the soil occupied by the hyphae. For both fungal species, measurements of ergosterol contents in P-containing soils were higher than 
those measured in soils without added P (Tab. II), confirming the better fungal development observed macroscopically. In addition, if we use ergosterol contents measured in the mycelia grown in pure culture in liquid medium (N6) which are 3 and $6 \mu \mathrm{g}$ ergosterol $\cdot \mathrm{mg}^{-1} \mathrm{dw}$ in $H$. cylindrosporum and $R$. roseo$l u s$, respectively (Plassard, unpublished), active fungal biomass contents in the soil colonised by $H$. cylindrosporum are always higher than those of $R$. roseolus (Tab. II).

Measurements of $\mathrm{pH}$ carried out in water soil suspensions without and with fungal colonisation are given in Table II. The comparison of $\mathrm{pH}$ values showed that in every soil treatment, $H$. cylindrosporum development did not modify soil $\mathrm{pH}$ whereas $R$. roseolus tended to acidify the soil $\mathrm{pH}$. This was particularly apparent when phosphorus was added to the soil.

As expected, measurements of oxalate contents in the soil showed that no oxalate was detected after culture of $H$. cylindrosporum whereas the reverse situation was observed with $R$. roseolus (Tab. II). The greatest oxalate contents measured in P-supplemented soils (HA and MKP) were probably related to better development of the fungus.

\subsection{Fungi grown in association with the plant}

\subsubsection{Plant and fungal development}

During the culture in rhizoboxes, plants were able to grow. Non-inoculated plants developed roots over the soil surface, especially at the base of the box. After 2 months of culture, ectomycorrhizal plants presented abundant fungal development starting from the ectomycorrhizal roots to the surrounding soil, increasing the exploration of soil (Fig. 2). Macroscopic observations showed that hyphae of $H$. cylindrosporum were less abundant than those of $R$. roseolus, developing dense fungal mats on the soil surface. As in pure culture, stereomicroscope observations showed that hyphae of $H$. cylindrosporum fully colonised the soil in depth whereas those of $R$. roseolus remained at the surface, making it possible to detach the hyphae from the soil easily. Ergosterol contents measured in the soil and plants are given in Table III. Soil or roots from control plants did not present detectable contents of ergosterol, indicating that these plants remained without fungal contamination. For both fungal species, ergosterol contents in soil were one to two orders of magnitude lower than those assayed in the roots (Tab. II), indicating that most of the external hyphae were sampled with mycorrhizal roots. Calculations of fungal biomass using the specific conversion factors given previously (see Sect. 3.1) show that the active fungal biomass contents associated with the roots ranged from 36 to $42 \mathrm{mg} \cdot \mathrm{g}^{-1}$ root dw and from 20 to $86 \mathrm{mg} \cdot \mathrm{g}^{-1}$ root dw in $H$. cylindrosporum and $R$. roseolus plants, respectively. At the time of harvest, addition of hydroxylapatite was the only treatment significantly increasing soil and root ergosterol concentration of $H$. cylindrosporum. The addition of both forms of $\mathrm{P}$, especially MKP, to the soil significantly increased $R$. roseolus development in roots and at the soil surface.

\subsubsection{Rhizosphere $\mathrm{pH}$}

Measurements of $\mathrm{pH}$ on the surface of roots and hyphae (Tab. IV) showed that slightly acidic values were recorded on

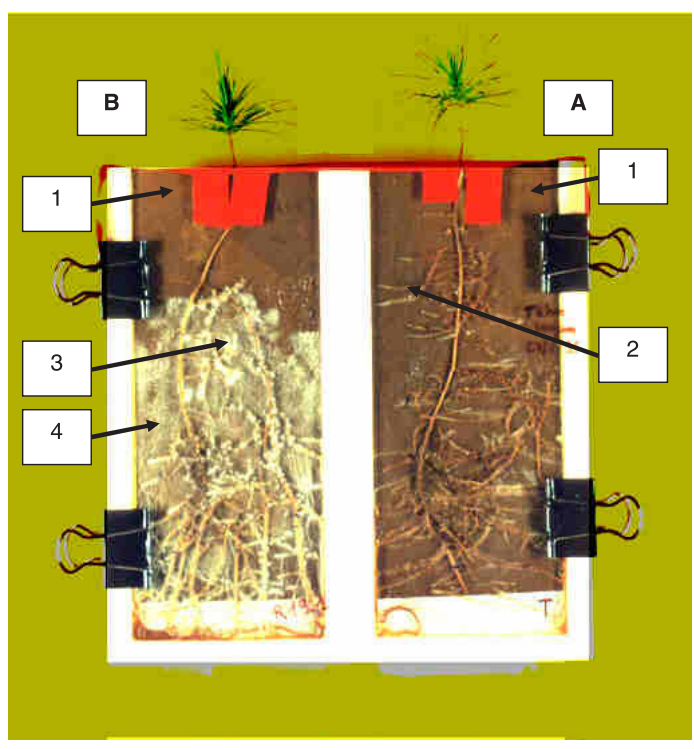

Figure 2. Root development of control (A) or $R$. roseolus ectomycorrhizal (B) Pinus pinaster plants grown in rhizoboxes for 2 months on the surface of a thin layer ( $500 \mu \mathrm{m}$ thick) of soil. 1/ Bulk soil; 2/ non-mycorrhizal roots; 3/ ectomycorrhizae; 4/ external mycelium.

Table III. Ergosterol contents in rhizosphere soil and roots of Pinus pinaster plants, either non-mycorrhizal (control) or associated with two ectomycorrhizal basidiomycetes, Rhizopogon roseolus (R.r) and Hebeloma cylindrosporum (H.c). Plants were grown on the surface of a thin layer of soil and rhizosphere soil corresponded to the soil previously occupied either by the roots (control) or by the ectomycorrhizal roots and the external hyphae (R.r and H.c). Ectomycorrhizal roots comprised ectomycorrhizae and external mycelium. The soil was used either without any treatment (NT) or after addition of calcium carbonate $\left(200 \mathrm{~g} \cdot \mathrm{kg}^{-1}\right.$ dry soil $)\left(\mathrm{CaCO}_{3}\right)$, or $\mathrm{P}\left(350 \mathrm{mg} \cdot \mathrm{kg}^{-1}\right.$ dry soil) supplied as hydroxylapatite (HA) or $\mathrm{KH}_{2} \mathrm{PO}_{4}(\mathrm{MKP})$. Data are means \pm standard deviation $(n=5)$.

\begin{tabular}{|c|c|c|c|c|c|}
\hline \multirow[b]{2}{*}{ Ergosterol } & \multirow{2}{*}{$\begin{array}{l}\text { Plant } \\
\text { type }\end{array}$} & \multicolumn{4}{|c|}{ Soil treatment } \\
\hline & & NT & $\mathrm{CaCO}_{3}$ & HAP & MKP \\
\hline In soil & Control & $\mathrm{nd}^{*}$ & nd & nd & nd \\
\hline \multirow[t]{2}{*}{$\left(\mu \mathrm{g} \cdot \mathrm{g}^{-1} \mathrm{~d}\right.$ soil $)$} & H.c & $3.4 \pm 1.3^{\mathrm{b} \$} \mathrm{~b} \$ \$$ & $2.5 \pm 1.7^{\mathrm{a}} \mathrm{b}$ & $11.2 \pm 3.1_{\mathrm{a}}^{\mathrm{a}}$ & $3.1 \pm 2.2^{\mathrm{a}} \mathrm{b}$ \\
\hline & R.r & $11.9 \pm 4.3^{\mathrm{a}}{ }_{\mathrm{a}}$ & $5.7 \pm 3.6^{\mathrm{a}} \mathrm{a}$ & $10.8 \pm 2.9^{\mathrm{a}}{ }_{\mathrm{a}}$ & $9.2 \pm 5.9^{\mathrm{a}} \mathrm{a}$ \\
\hline In roots & Control & $\mathrm{nd}^{\mathfrak{f}}$ & nd & nd & nd \\
\hline \multirow[t]{2}{*}{$\left(\mu \mathrm{g} \cdot \mathrm{g}^{-1} \mathrm{dw}\right)$} & H.c & $110 \pm 43^{\mathrm{a} \$} \mathrm{~b} \$$ & $114 \pm 10^{\mathrm{a}} \mathrm{b}$ & $211 \pm 20^{\mathrm{b}}{ }_{\mathrm{a}}$ & $128 \pm 56^{\mathrm{b}}{ }_{\mathrm{b}}$ \\
\hline & R.r & $125 \pm 9^{\mathrm{a}}{ }_{\mathrm{c}}$ & $114 \pm 28^{\mathrm{a}}{ }_{\mathrm{c}}$ & $363 \pm 90^{\mathrm{a}}{ }_{\mathrm{b}}$ & $521 \pm 39^{\mathrm{a}}{ }_{\mathrm{a}}$ \\
\hline
\end{tabular}

$*$ : nd $=$ not detectable $\left(<1.2 \mu \mathrm{g}\right.$ ergosterol $\cdot \mathrm{g}^{-1}$ dry soil $) ;{ }^{\$}$ : in each column, means followed by a different superscript letter are significantly different at $P=0.05 ; \$$ : in each line, means followed by a different subscript letter are significantly different at $P=0.05 ;{ }^{£}:$ nd $=$ not detectable ( $<4 \mu \mathrm{g}$ ergosterol $\cdot \mathrm{g}^{-1}$ dry weight of root). 
Table IV. Values of $\mathrm{pH}$ measured on the surface of bulk soil, nonmycorrhizal (NM) roots, ectomycorrhizal short roots (ECM) and external mycelium (Mycelium) of Pinus pinaster plants, either nonmycorrhizal (control) or associated with two ectomycorrhizal basidiomycetes, Rhizopogon roseolus (R.r) and Hebeloma cylindrosporum (H.c). Plants were grown on the surface of a thin layer of soil used either without any treatment (NT) or after addition of $\mathrm{CaCO}_{3}(20 \%$, w/w) $\left(\mathrm{CaCO}_{3}\right)$, or $350 \mathrm{mg} \mathrm{P} \cdot \mathrm{kg}^{-1}$ dry soil supplied as hydroxylapatite $(\mathrm{HA})$ or $\mathrm{KH}_{2} \mathrm{PO}_{4}(\mathrm{MKP})$. Data are means \pm standard deviation $(\mathrm{n}=5)$.

\begin{tabular}{lccccc}
\hline $\begin{array}{l}\text { Location of } \mathrm{pH} \\
\text { measurement }\end{array}$ & $\begin{array}{c}\text { Plant } \\
\text { type }\end{array}$ & $\mathrm{NT}$ & $\mathrm{CaCO}_{3}$ & $\mathrm{HA}$ & MKP \\
\hline Bulk soil & & $7.1 \pm 0.2$ & $7.8 \pm 0.10$ & $7.0 \pm 0.2$ & $7.3 \pm 0.2$ \\
NM roots & Control & $5.1 \pm 0.1$ & $4.8 \pm 0.2$ & $4.8 \pm 0.3$ & $5.2 \pm 0.3$ \\
ECM & R.r & $4.2 \pm 0.2$ & $\leq 4.0$ & $4.3 \pm 0.3$ & $4.8 \pm 0.3$ \\
& H.c & $6.4 \pm 0.4$ & $6.3 \pm 0.3$ & $6.5 \pm 0.4$ & $5.6 \pm 0.3$ \\
Mycelium & R.r & $4.8 \pm 0.2$ & $5.6 \pm 0.8$ & $4.8 \pm 0.5$ & $4.9 \pm 0.4$ \\
& H.c & $7.0 \pm 0.2$ & $7.8 \pm 0.2$ & $6.9 \pm 0.3$ & $7.0 \pm 0.3$ \\
\hline
\end{tabular}

the surface of non-mycorrhizal roots, whatever the soil treatment. This acidification could be due either to respiratory $\mathrm{CO}_{2}$ released from the roots or to proton release due to cation excess uptake. Ectomycorrhizal association with $R$. roseolus led to more acidic values, especially with $\mathrm{CaCO}_{3}$ treatment. On the contrary, $H$. cylindrosporum ectomycorrhizae presented $\mathrm{pH}$ values higher than those measured in control roots. Similar trends were observed at the mycelium surface. It is worth noting that $R$. roseolus hyphae presented a $\mathrm{pH}$ value two units lower than the soil underneath. These $\mathrm{pH}$ modifications on the surface of roots or hyphae led to $\mathrm{pH}$ values in the rhizosphere soil differing from those in the bulk soil (Tab. V). It can be noticed that in the absence of $\mathrm{CaCO}_{3}$, ectomycorrhizal roots of $R$. roseolus led to $\mathrm{pH}$ values lower than those of the bulk soil. On the contrary, no significant acidification was recorded for the two other types of plant whatever the soil treatment.

\subsubsection{Oxalate contents}

Oxalate contents of roots are given in Table VI. For mycorrhizal plants, only the mycorrhizal parts of the root system were analysed. Measurements of oxalate in these roots did not discriminate between oxalate accumulated inside or on the surface of roots or hyphae. Whatever the soil treatment, nonmycorrhizal roots of control plants or ectomycorrhizal roots of $H$. cylindrosporum plants contained low levels of oxalate. On the contrary, ectomycorrhizal roots of $R$. roseolus plants contained great amounts of oxalate, especially in the presence of $\mathrm{CaCO}_{3}$ in the soil. Differences between the two fungal species were confirmed by scanning electron microscopy that showed the presence of numerous bipyramidal quadratic crystals characteristic of weddelite $\left(\mathrm{CaC}_{2} \mathrm{O}_{4}, 2 \mathrm{H}_{2} \mathrm{O}\right)$ on the surface of $R$. roseolus hyphae (Fig. 3). On the contrary, H. cylindrosporum hyphae did not present any crystals (data not shown).

In the rhizosphere soil, only ectomycorrhizal roots of $R$. roseolus gave measurable amounts of oxalate (Tab. VI). Once again, the presence of $\mathrm{CaCO}_{3}$ in the soil enhanced oxalate contents assayed in the rhizosphere soil of $R$. roseolus plants.
Table V. Values of $\mathrm{pH}$ measured in the rhizosphere soil suspended in water $(1 / 2.5, \mathrm{w} / \mathrm{v})$ before and after the culture of Pinus pinaster plants, either non-mycorrhizal (control) or associated with two ectomycorrhizal basidiomycetes, Rhizopogon roseolus (R.r) and Hebeloma cylindrosporum (H.c). Plants were grown on the surface of a thin layer of soil and rhizosphere soil corresponded to the soil previously occupied either by the roots (control) or by the ectomycorrhizal roots and the external hyphae (R.r and H.c). The soil was used either without any treatment (NT) or after addition of $\mathrm{CaCO}_{3}(20 \%$, w/w) $\left(\mathrm{CaCO}_{3}\right)$, or $350 \mathrm{mg} \mathrm{P} \cdot \mathrm{kg}^{-1}$ dry soil supplied as hydroxylapatite $(\mathrm{HA})$ or $\mathrm{KH}_{2} \mathrm{PO}_{4}(\mathrm{MKP})$. Data are means $(\mathrm{n}=5)$.

\begin{tabular}{lccccc}
\hline & Plant & \multicolumn{4}{c}{ Soil treatment } \\
$\mathrm{pH}\left(\mathrm{H}_{2} \mathrm{O}\right)$ & type & $\mathrm{NT}$ & $\mathrm{CaCO}_{3}$ & $\mathrm{HA}$ & $\mathrm{MKP}$ \\
\hline Initial & & $7.10^{\mathrm{a} \$}{ }_{\mathrm{c} \$ \$}$ & $7.55^{\mathrm{a}}{ }_{\mathrm{a}}$ & $7.16^{\mathrm{a}}{ }_{\mathrm{c}}$ & $7.37^{\mathrm{a}}{ }_{\mathrm{b}}$ \\
After culture & Control & $6.97^{\mathrm{a}}{ }_{\mathrm{c}}$ & $7.46^{\mathrm{a}}{ }_{\mathrm{a}}$ & $6.87^{\mathrm{b}}{ }_{\mathrm{c}}$ & $7.17^{\mathrm{b}}{ }_{\mathrm{b}}$ \\
& H.c & $7.21^{\mathrm{a}}{ }_{\mathrm{ab}}$ & $7.59^{\mathrm{a}}{ }_{\mathrm{a}}$ & $6.93^{\mathrm{b}}{ }_{\mathrm{b}}$ & $7.42^{\mathrm{a}}{ }_{\mathrm{a}}$ \\
& R.r & $5.78^{\mathrm{b}}{ }_{\mathrm{b}}$ & $7.26^{\mathrm{b}}{ }_{\mathrm{a}}$ & $5.67^{\mathrm{c}}{ }_{\mathrm{b}}$ & $5.71^{\mathrm{c}}{ }_{\mathrm{b}}$ \\
\hline
\end{tabular}

$\$:$ in each column, means followed by a different superscript are significantly different at $P=0.05 ; \$$ : in each line, means followed by a different subscript are significantly different at $P=0.05$.

Table VI. Oxalate contents in rhizosphere soil and roots of Pinus pinaster plants, either non-mycorrhizal (control) or associated with two ectomycorrhizal basidiomycetes, Rhizopogon roseolus (R.r) and Hebeloma cylindrosporum (H.c). Plants were grown on the surface of a thin layer of soil and rhizosphere soil corresponded to the soil previously occupied either by the roots (control) or by the ectomycorrhizal roots and the external hyphae (R.r and H.c). Ectomycorrhizal roots comprised ectomycorrhizae and external mycelium. The soil was used either without any treatment (NT) or after addition of $\mathrm{CaCO}_{3}\left(20 \%\right.$, w/w) $\left(\mathrm{CaCO}_{3}\right)$, or $350 \mathrm{mg} \mathrm{P} \cdot \mathrm{kg}^{-1}$ dry soil supplied as hydroxylapatite (HA) or $\mathrm{KH}_{2} \mathrm{PO}_{4}(\mathrm{MKP})$. Data are means $(\mathrm{n}=5)$.

\begin{tabular}{lccccc}
\hline Oxalate & Plant & \multicolumn{4}{c}{ Soil treatment } \\
$\left(\mathrm{C}_{2} \mathrm{O}_{4}{ }^{2-}\right)$ & type & $\mathrm{NT}$ & $\mathrm{CaCO}_{3}$ & $\mathrm{HA}$ & $\mathrm{MKP}$ \\
\hline In roots & Control & $11.1^{\mathrm{b} \$} \mathrm{~b} \$$ & $21.0^{\mathrm{b}}{ }_{\mathrm{a}}$ & $8.9^{\mathrm{b}}{ }_{\mathrm{b}}$ & $7.9^{\mathrm{b}}{ }_{\mathrm{b}}$ \\
$\left(\mu \mathrm{mol} \cdot \mathrm{g}^{-1} \mathrm{dw}\right)$ & H.c & $9.0^{\mathrm{b}}{ }_{\mathrm{b}}$ & $20.7^{\mathrm{b}}{ }_{\mathrm{a}}$ & $7.9^{\mathrm{b}}{ }_{\mathrm{b}}$ & $7.4^{\mathrm{b}}{ }_{\mathrm{b}}$ \\
& R.r & $63^{\mathrm{a}}{ }_{\mathrm{c}}$ & $317^{\mathrm{a}}{ }_{\mathrm{a}}$ & $147^{\mathrm{a}}{ }_{\mathrm{b}}$ & $169^{\mathrm{a}}{ }_{\mathrm{b}}$ \\
In soil & Control & $\mathrm{nd}^{*}$ & $\mathrm{nd}$ & $\mathrm{nd}$ & $\mathrm{nd}$ \\
$\left(\mu \mathrm{mol} \cdot \mathrm{g}^{-1} \mathrm{~d}\right.$ soil $)$ & H.c & $\mathrm{nd}^{*}$ & $\mathrm{nd}$ & $\mathrm{nd}$ & $\mathrm{nd}$ \\
& R.r & $47.5_{\mathrm{b} \$} \$$ & $137_{\mathrm{a}}$ & $52_{\mathrm{b}}$ & $63_{\mathrm{b}}$ \\
\hline
\end{tabular}

$\$$ : in each column, means followed by a different superscript are significantly different at $P=0.05 ; \$$ : in each line, means followed by a different subscript are significantly different at $P=0.05$; *: nd $=$ not detectable $\left(<0.2 \mu \mathrm{mol} \mathrm{C}_{2} \mathrm{O}_{4}{ }^{2-} \cdot \mathrm{g}^{-1}\right.$ dry soil).

\section{DISCUSSION}

\section{1. $\mathrm{pH}$ measurements}

Grown in pure culture with $\mathrm{NO}_{3}{ }^{-}$as the sole source of $\mathrm{N}$, both ectomycorrhizal fungi had different effects on soil $\mathrm{pH}$ : even with $\mathrm{CaCO}_{3}$ added to the soil, $R$. roseolus tended to acidify soil $\mathrm{pH}$ whereas $H$. cylindrosporum tended to alkalinise it 


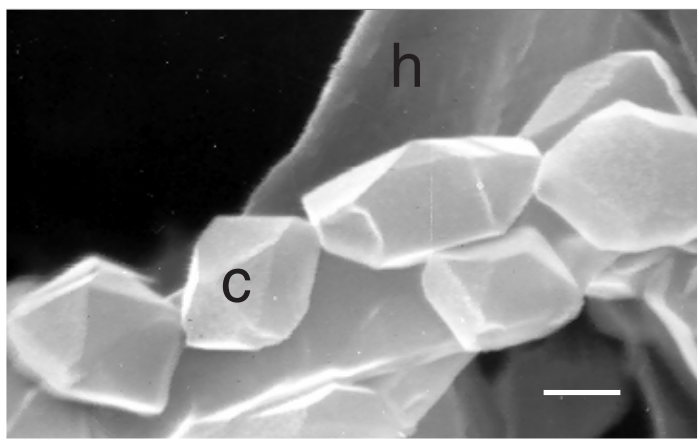

Figure 3. Oxalate crystals (C) accumulated at the surface of $R$. roseolus hyphae (h) grown in association with $P$. pinaster in minirhizoboxes $(\mathrm{bar}=1 \mu \mathrm{m})$.

(Tab. II). This confirmed previous studies carried out on these fungal species grown in liquid medium $[1,19]$.

The use of rhizoboxes specifically designed for these experiments enabled us to grow non-mycorrhizal Pinus pinaster plants and mycorrhizal plants with an extensive fungal development, on the surface of a thin layer of soil (Fig. 2). Therefore this device appears relevant for extending the observations obtained with fungal species grown in vitro to complete ectomycorrhizal systems. Several ectomycorrhizal associations have been grown on the surface of soil layers placed in Perspex microcosms (for an example see [4, 23]). However, the soil layer used in these microcosms was thicker than in our rhizoboxes and was not continuously supplied with a nutritive solution. On the other hand, we used sterile material to set up the experiment, but then the plants were grown in non-sterile conditions. Therefore, bacterial contamination of soil and roots could have occurred during the growth period and could have either contributed to, or modified, the rhizosphere effects we observed. Although we did not precisely quantify the significance of the possible bacterial colonisation, images from scanning electron microscopy (not shown) did not show the presence of any bacteria in $R$. roseolus plants. Nevertheless, in $H$. cylindrosporum plants, we got one image showing some bacteria-like particles $1 \mu \mathrm{m}$ wide and $2 \mu \mathrm{m}$ long on the soil surface. However, the size of these particles was 10 times higher than that of the bacteria shown in the mycorrhizosphere of intact Pinus sylvestris plants grown in Perspex microcosms containing a non-sterile humus layer [23] Although we cannot exclude such bacterial contamination in our experimental systems, this appears to be either low (R. roseolus plants) or uncertain (H. cylindrosporum plants).

Our culture device made it possible to measure different local $\mathrm{pH}$ values, either on the fresh plant material or in the soil solution. Measuring $\mathrm{pH}$ on the surface of the different types of roots (non-mycorrhizal and mycorrhizal) or external mycelium developing in the soil enables us to estimate the actual release of protons in the water layer surrounding the plant or fungal material, without any dilution of $\left[\mathrm{H}^{+}\right]$, as would occur with other methods [27]. Our results showed that, whatever the soil treatment, $R$. roseolus and H. cylindrosporum ectomycorrhizal roots exhibited lower and higher $\mathrm{pH}$ values, respectively, than those measured on the surface of non-mycorrhizal roots. The same trends were observed at the level of external mycelium, although differences between $\mathrm{pH}$ values from the soil underneath and the hyphae were lower than in ectomycorrhizal roots. This could be due to greater amounts of active hyphae in ectomycorrhizae than in external mycelium. Our results indicate that a net efflux ( $R$. roseolus) or influx (H. cylindrosporum) of protons was due to the presence of the fungus associated with the roots. This is consistent with data obtained in both fungal species grown in vitro in nitrate liquid medium $[1,19]$. It was also demonstrated that $R$. roseolus grown in pure culture was able to lower the $\mathrm{pH}$ of a nitrateagar gel containing $\mathrm{CaCO}_{3}[1,19]$, as observed in this study. Taken as a whole, these results indicate that the ability of $R$. roseolus to release protons with nitrate nutrition in vitro is maintained when this fungal species is associated with $P$. pinaster. In addition, $\mathrm{H}^{+}$efflux is great enough to modify the $\mathrm{pH}$ of rhizosphere soil (Tab. V).

\subsection{Oxalate production}

Measurements of oxalate contents in the soil and plants also differed between fungi. Grown in pure culture H. cylindrosporum did not release oxalate, contrary to $R$. roseolus (Tab. II). These observations are consistent with those obtained previously in liquid medium $[1,19]$. However, oxalate contents measured in HA-supplied soil colonised by $R$. roseolus hyphae were more variable than the corresponding ergosterol content, suggesting that oxalate production may not strictly depend upon the living hyphae. Oxalate accumulation may correlate better with the total fungal biomass grown over the whole duration of the experiment. The total fungal biomass in artificial substrate has been successfully estimated using chitin assay [28]. However, in a preliminary study, we found that the presence of our soil strongly interacted with the chitin assay, preventing us from getting this chemical estimation of the total fungal biomass. Nevertheless, using the rhizoboxes we designed, it was possible to study the distribution of oxalate between roots and rhizosphere soil. Plant analysis showed that $H$. cylindrosporum ectomycorrhizal roots (comprising external hyphae) had low oxalate contents similar to those measured in control roots (Tab. VI), suggesting that most of the oxalate could be produced by the root alone, as shown in Picea abies roots [3]. In contrast, $R$. roseolus ectomycorrhizal roots and external hyphae contained high levels of oxalate that can be attributed to fungal oxalate which at least partly accumulates on the surface of hyphae (Fig. 3). Addition of $\mathrm{CaCO}_{3}$ enhanced the oxalate content of mycorrhizal roots (ectomycorrhizae and mycelium) by 2 to 5 times. This increase was not related to the contents of fungal ergosterol in $R$. roseolus ectomycorrhizal roots (compare Tabs. III and VI), suggesting that $\mathrm{CaCO}_{3}$ per se could be the main soil factor enhancing oxalate production. This effect of $\mathrm{CaCO}_{3}$ was previously observed in white-rot fungi [2], while there is no information available on woody plants. In ectomycorrhizal fungi, it was demonstrated that increasing concentrations of $\mathrm{NaHCO}_{3}$ in culture medium enhanced oxalate production in $P$. involutus [18] by incorporation of $\mathrm{HCO}_{3}{ }^{-}$ions during oxalate biosynthesis [17]. In our culture conditions, where roots are growing in a nearly confined atmosphere, the carbonate solid phase of soil and $\mathrm{CO}_{2}$ arising from fungal or plant respiration react 


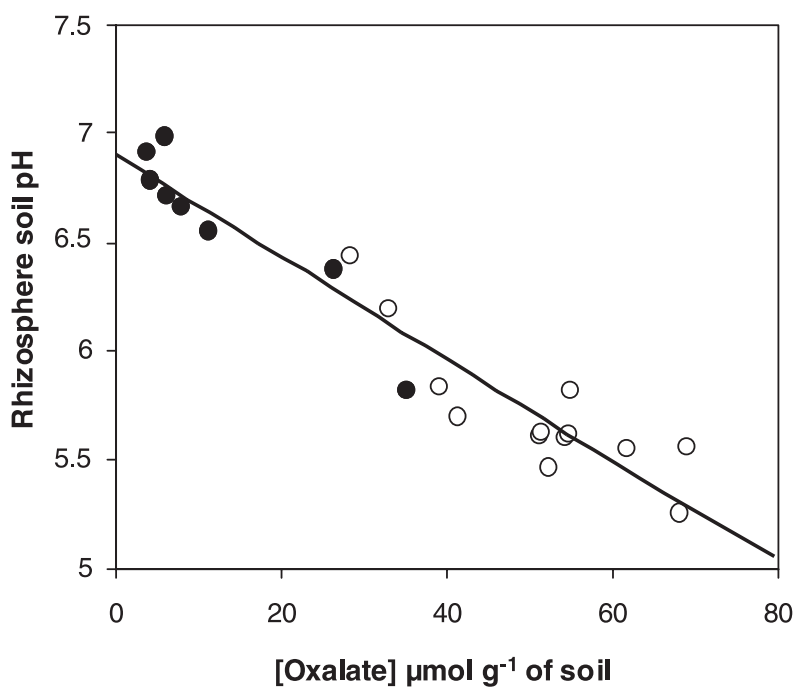

Figure 4. Relationship between oxalate contents and $\mathrm{pH}$ of the rhizosphere soil harvested under the hyphae of the ectomycorrhizal fungus Rhizopogon roseolus grown in pure culture (closed symbols) or in association with Pinus pinaster (open symbols). The equation of the linear regression drawn on the figure is $\mathrm{y}=6.90-0.0236 \times\left(\mathrm{R}^{2}=\right.$ 0.922).

together to produce $\mathrm{HCO}_{3}{ }^{-}$in soil solution, the concentration of which could be high enough to enhance oxalate synthesis. The addition of $\mathrm{P}$ to the soil increased the content of oxalate and ergosterol in $R$. roseolus ectomycorrhizal roots. This suggests that the observed increment of oxalate could be due to a better development of fungal hyphae rather than to a specific effect of $\mathrm{P}$ on oxalate production.

Soil analysis showed that oxalate accumulation was measured only in the rhizosphere of $R$. roseolus plants corresponding to the soil sampled under roots and external hyphae, after harvest of the roots and hyphae. Similarly to the root contents, soil oxalate contents were higher with $\mathrm{CaCO}_{3}$ in the soil and this effect could be explained by the same mechanism previously described for roots. The greater the oxalate contents in the roots, the greater the oxalate contents in the soil, suggesting that oxalate synthesised in ectomycorrhizae and mycelium could be released into the soil.

The method we used to extract oxalate from the soil did not enable us to distinguish between the chemical forms of oxalate after its release. These could be insoluble calcium oxalate (as shown in Fig. 3) or soluble complexes with iron or aluminium. Oxalate could also be adsorbed on soil constituents, particularly with Fe oxides that are abundant in this soil. Nevertheless, whatever the chemical form of oxalate, a close relationship can be established between $\mathrm{pH}$ values and oxalate contents of rhizosphere soil after culture of $R$. roseolus. Indeed, when considering individual values measured in all replicates concerning soil treatments (NT, HA and MKP) we were able to establish a tight correlation between $\mathrm{pH}$ and oxalate contents in rhizosphere soil (Fig. 4). The linear relationship indicates that protons and oxalate anions are released simultaneously during transport of oxalate out of the cell. Oxalate is trans- ported in ionic form because the cytosolic $\mathrm{pH}$ (around 7) is higher than the $\mathrm{pK}$ of oxalic acid (pK for oxalate ${ }^{-} /$oxalate $^{2-}$ is $4.19)[13,14]$, meaning that the organic acid is actually present as an organic anion in the cytosol. Therefore, as underlined by Roelofs et al. [29], when carboxylates are exuded as anions, their charge could be balanced by a cation efflux such as $\mathrm{C}_{2} \mathrm{O}_{4}{ }^{2-} / 2 \mathrm{H}^{+}$. Such a symport would have an acidifying effect, as we observed in Figure 4. However, the buffering effect of the soil did not make it possible to determine the actual stoechiometry between oxalate and proton release.

Acknowledgements: We thank Michaël Clairotte and Lucien Roger for their excellent technical assistance and Dr. Benoît Jaillard for valuable discussions. Financial support from Brazil (Consehlo Nacional de Desenvolvimento Cientifico e Technologico) and the European Commission (contract number AIR2-CT-94-1149) is gratefully acknowledged.

\section{REFERENCES}

[1] Arvieu J.C., Leprince F., Plassard C., Release of oxalate and protons by ectomycorrhizal fungi in response to P-deficiency and calcium carbonate in nutrient solution, Ann. For. Sci. (2002) in press.

[2] Dutton M.V., Evans C.S., Oxalate production by fungi: its role in pathogenicity and ecology in the soil environment, Can. J. Microbiol. 42 (1996) 881-895.

[3] Fink S., Occurrence of calcium oxalate crystals in nonmycorrhizal fine roots of Picea abies, J. Plant Physiol. 147 (1992) 137-140.

[4] Finlay R.D., Read D.J., The structure and function of the vegetative mycelium of ectomycorrhizal plants. I. Translocation of ${ }^{14} \mathrm{C}$-labelled carbon between plants interconnected by a common mycelium, New Phytol. 103 (1986) 143-156.

[5] Gadd G.M., Fungal production of citric and oxalic acid: importance in metal speciation, physiology and biogeochemical processes, Adv. Microbiol. Physiol. 41 (1999) 47-92.

[6] Gahoonia T.S., Claasen N., Junkg A., Mobilization of phosphate in different soils by ryegrass supplied with ammonium or nitrate, Plant and Soil 140 (1992) 241-248.

[7] Gharieb M.M., Gadd G.M., Influence of nitrogen source on the solubilization of natural gypsum and the formation of calcium oxalate by different oxalic and citric acid-producing fungi, Mycol. Res. 103 (1999) 473-481.

[8] Hayek E., Stadlmann W., Darstellung von reinem hydroxylapatits für adsorptionzwecke, Angew. Chem. 67 (1955) 327.

[9] Hinsinger P., Plassard C., Tang C., Jaillard B., Origins of rootmediated $\mathrm{pH}$ changes in the rhizosphere and their responses to environmental constraints - a review, Plant and Soil 248 (2003) 43-59.

[10] Hinsinger P., Gilkes R.J., Root-induced dissolution of phosphate rock in the rhizosphere of Lupins grown in alkaline soil, Aust. J. Soil Res. 33 (1995) 477-489.

[11] Hinsinger P., Gilkes R.J., Dissolution of phosphate rock in the rhizosphere of five plants species grown in an acid, P-fixing mineral substrate, Geoderma 75 (1997) 231-249.

[12] Jaillard B., Plassard C., Hinsinger P., Measurements of $\mathrm{H}^{+}$fluxes and concentrations in the rhizosphere, in: Rengel Z. (Ed.), The handbook of soil acidity, Marcel Dekker, 2002, in press

[13] Jones D.L., Organic acids in the rhizosphere-a critical review, Plant and Soil 205 (1998) 25-44.

[14] Jones D.L., Brassington D.S., Sorption of organic acids in acid soils and its implications in the rhizosphere, Eur. J. Soil Sci. 49 (1998) 447-455. 
[15] Kanabo I., Gilkes R.J., The role of soil $\mathrm{pH}$ in the dissolution of phosphate rock fertilisers, Fertil. Res. 12 (1987) 165-174.

[16] Kirk G., Santos E., Santos M., Phosphate solubilization by organic anion excretion from rice growing in aerobic soil: rates of excretion and decomposition, effects on rhizosphere $\mathrm{pH}$ and effects on phosphate solubility and uptake, New Phytol. 142 (1999) $185-200$

[17] Lapeyrie F., Oxalate synthesis from soil bicarbonate by the mycorrhizal fungus Paxillus involutus, Plant and Soil 110 (1988) 3-8.

[18] Lapeyrie F., Chilvers G.A., Bhem C.A., Oxalic acid synthesis by the mycorrhizal fungus Paxillus involutus (Batsch. ex fr.), New Phytol. 106 (1987) 139-146.

[19] Leprince F., Mécanismes mis en œuvre par différents champignons ectomycorhiziens dans la mobilisation du phosphore, $\mathrm{Ph}$.D. Thesis, École Nationale Supérieure Agronomique Montpellier, France, 1995.

[20] Mackay A.D., Syers J.K., Effect of phosphate, calcium, and pH on the dissolution of a phosphate rock in soil, Fertil. Res. 10 (1986) 175-184.

[21] Marschner H., Mineral Nutrition of Higher Plants, 2nd ed., Academic Press, London, 1995.

[22] Morizet S., Mingeau M., Influence des facteurs du milieu sur l'absorption hydrique. 1. Facteurs nutritionnels, Ann. Agron. 27 (1976) 183-205.

[23] Nurmiaho E.L., Timonen S., Haahtela K., Sen R., Bacterial colonization patterns of intact Pinus sylvestris mycorrhizosphere in dry pine forest soil: an electron microscopy study, Can. J. Microbiol. 43 (1997) 1017-1035.

[24] Nye P.H., Kirk G.J., The mechanism of rock phosphate solubilization in the rhizosphere, Plant and Soil 100 (1987) 127-134.

[25] Piombo G., Babre D., Fallavier P., Cazevielle P., Arvieu J.C., Callot G., Oxalate extraction and determination by ionic chromatography in calcareous soil and in mycorrhized roots environment, Commun. Soil Sci. Plant Anal. 27 (1996) 1663-1677.

[26] Plassard C., Barry D., Eltrop L., Mousain D., Nitrate uptake in maritime pine (Pinus pinaster Soland in Ait.) and the ectomycorrhizal fungus Hebeloma cylindrosporum: effect of ectomycorrhizal symbiosis, Can. J. Bot. 72 (1994) 189-192.

[27] Plassard C., Meslem M., Souche G., Jaillard B., Localization and quantification of net fluxes of $\mathrm{H}^{+}$along roots by combined use of videodensitometry of dye indicator and ion-selective micro-electrodes, Plant and Soil 211 (1999) 29-39.

[28] Plassard C., Bonafos B., Touraine B., Differential effects of mineral and organic $\mathrm{N}$ sources, and of ectomycorrhizal infection by Hebeloma cylindrosporum, on growth and $\mathrm{N}$ utilisation in Pinus pinaster, Plant Cell Environ. 23 (2000) 1195-1205.

[29] Roelofs R.F.R., Rengel Z., Cawthray G.R., Dixon K.W., Lambers H., Exudation of carboxylates in Australian Proteaceae: chemical composition, Plant Cell Environ. 24 (2001) 891-904.

[30] Ruiz L., Mobilisation du Phosphore des Apatites dans la Rhizosphère. Rôle de l'Excrétion de Protons par les Racines, Ph.D. Thesis, Montpellier II University, France, 1992. 
V. Casarin et al. 